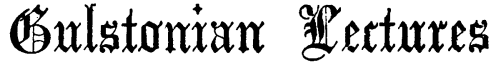

\author{
ON
}

\section{THE NATURE AND AFFINITIES OF TUBERCLE.}

Delivered at the Royal College of Physicians, 1867.

BY

REGLNALD SOUTHEY, M.D., F.R.C.P., ASSISTANT.PHYSICIAN TO ST. BARTHOLOMEW'S HOSPITAL, ETC.

LECTURE I.

THe name of Tubercle was applied by the old medical authors to any little tumour. The root tuber, from which this diminutive is derived, was used by Pliny, in speaking of the fruit of a variety of apple. Celsus uses tuberculum as a translation for the Greek $\pi$ ápovics, a gumboil.

Now, the subject which I propose should occupy us in to-day's lecture is, the Nature of Tubercle; but, before this can be discussed, we must agree to what we are to understand under this name. The term has been very vaguely used and indifferently attached to various morbid products, which really possess very little in common. In the lecture as $I$ originally delivered it, the opinions of Carswell, Rokitansky, and Lebert, were separately and at some length considered; but I shall here proceed at once to the latest and most definite views of tubercle that we possess, and which have been recently published by the author of the Cellular Pathology.

Tubercle, according to Virchow, is a new growth; and is classed by him among the lymph-tumoursthose, namely, which are constructed after the pattern of lymph-glands, and which stand most closely in relation to immediate connective tissue formations. (Die Krankhäften Geschwülste, Band II, s. 557.) The single tuberculum, or tubercle-tumour, is not capable of identification from any one element that enters into its composition; but its origin, development, and minute structure together, confer a particular stamp upon it, whereby it is rendered capable of distinct recognition. It will be necessary for me to describe the minute anatomy of tubercle, as this is to be generally gathered from Professor Virchow's writings and not a little from his teachings; for I had the privilege of learning much from him personally some few years ago.

The tubercle formation, he shows, is cell-structured from the moment of its first appearance; it proceeds always out of connective tissue, or from some tissue closely allied to this, such as false membrane, fat, or the medullary tissue of bone. It exists in two forms; the one he terms the cellular, the other the fibrous form; but they have such features in common as imply unmistakeable oneness. The fibrous form is only a slight structural modification of the simple cellular; a modification, as I shall hereafter have occasion to show, impressed upon it by the external conditions of its growth.

The origin and mode of development of the simple cellular form is best of all to be studied from the tuberculous growth, as this is found upon serous membranes, or upon the mucous membrane of the larynx, and, after these, in organs like the liver and kidney, which are endowed with a distinet stroma of their own. His description (Lib. ant. cit., p. 636) is from an example upon a serous membrane, the young growth is somewhat smaller than the smallest milletseed; it has a granular look, and contains soft imperfectly developed cells, which are very easily broken down, and free nuclei. Its elements, although differently grouped, are identical with those that constitute a normal lymph-gland.

The isolated tubercle forms the tiniest tumour that occurs in the human body; but it is rarely, if ever, single. These growths are almost always multiple; they are found in nest-like groups close together; and multitudes of nodules thus originally and individually distinct can amass together and form a conglomerate tumour.

Conglomerate tubercle increases in size by surface accretions; new nodules grow up in the tissue immediately round about the old ones ; and, as this accretion can take place from all sides around a centre in the parenchyma of solid organs, the final shape attained by the mass is round or roundish. But, upon free surfaces, the extension must follow the plane of the matrix tissue ; and hence the form ultimately attained is more or less flat or squat. The composition of tubercle is cellular, wherever the growth can pursue its natural course unobstructed.

In studying the features of a new growth, just as in the examination of any tissue, there is a point which must be borne in mind; namely, that the structures of which it is composed will present themselves in different stages of development.

1. There are the young embryonal elements, the cells which may be called indeterminate; such, for example, as those of connective tissue in the corium proper, the deeper layers of the cutis.

2. There are the determined or special cell and intercellular developments, which confer, by their shape or arrangement, its particular stamp or seal on the tissues to which they belong, as bone-cells to bone, cartilage-cells to cartilage, and tubercle-cells to tubercle.

3. There are the forms presented by the structures in process of disintegration towards removal in situ; such, for example, as are the dried, broken, granulised upper scales of effete epidermis, the fatty degenerate mucous cells from mucous surfaces, the central fine granules of tubercular débris.

Now, the pathognomonic features of a new growth, like the characteristic elements of any normal tissue, must be especially read and estimated at the second stage, when the component parts have attained to their highest stage of perfection. This is a sort of pause period, which is of very different duration in different tissues. It is at this pause that those structural features predominate, which enable us to form an opinion upon the nature of the growth ; it must be further remembered, that the elements of greatest permanency in an adventitious product do not by any means necessarily correspond with the structures of highest aim in it.

It is true that the distinguishing elements of a healthy tissue are not only present in greatest abundance, but are themselves most permanent at the period when they are most characteristic. But almost the very converse of this might be announced of abnormal growths; their stage of greatest permanency is invariably somewhat removed from that of their highest perfection; they incline always to continue longest either in their embryonal or in their degenerative stage. Tubercle, as an instance in point, can be affirmed to do both; since, in its cellular form, the tendency is to pass most rapidly towards, and to remain most permanently at the degenerative stage, and in its fibrous form at the embryonal:

In studying the histology of the isolated grey 
nodule, which is the most honest sample and purest specimen of tubercle, the three stages of development above described are all most distinctly visible. Outermost lie the connective tissue cells in process of endogenous proliferation; that is, multiplying by producing new cells in the interior of old ones. Next come the highest aimed structures which the growth reaches, the cell-forms most characteristic of it, which are disposed in an irregular ring round the centre, and which perhaps multiply themselves by fissiparous development. And, lastly, placed most centrally in the examples offered by tubercle in the stroma of solid organs, granular amorphous bodies can be seen, which might not be inaptly termed the products of the eremacausis, or smouldering combustion of animal tissues. Commensurately with the age of the growth, these fine granules and fatty compounds, significant of the stage of decay, enoroach upon and predominate over the cellular structures.

The tubercle-cell, says Wedl (Pathol. Histol., pp. 367 and 388)-and this is not that cell on which Glüge and Lebert laid such stress, that was a compound granular corpuscle, an element of much later formation in the stage of caseous metamorphosis-is a real cell, not a nucleus or a solid body; it is usually smaller than a white blood-cell, but it can attain to double or treble this size; it is round, like the leukæmic, typhoma, or scrofulous cell, and belongs to the nature of a lymph-gland element; it is colourless, transparent, and faintly granular. When fully developed, a shining nucleus is to be seen in its interior-a nucleus which, in some instances, is small and homogeneous; in others, more granular and nucleolated. A few of these cells have two or more nuclei.

Although the outer layer of the middle ring is thus indisputably composed of perfect cells, between which a fine reticulated meshwork of connective tissue fibrillations extends; still, by gradual transition, a layer of what cannot be distinguished from free nuclei is quickly reached, and these are packed so close together as to admit the interposition of no interstitial substance whatsoever ; further, the transition from these again to the amorphous central granules is through a series of gradually diminishing nuclear forms. The multiplication of nuclei peculiar to the outer layer of connective tissue is, says Virchow (Archiv, b. xiv, s. 49), to be seen to greatest advantage in the tubercular growths which proceed out of the fat-cells of the omentum. Here the fat is first absorbed; the nuclei in the interior of the cells divide by repeated fission; they multiply so as to distend the cells to gigantic size; and ure pressed so close together, that it is easy to imagine one is looking at nothing but free nuclei.

Now, if the nature of the tuberculous growth had to be decided upon the intrinsic value of some one of its component elements, it would be to these angular shaped free nuclei thus herded together that I should attribute most paramount importance. Its cells, although there are heterologous, wrongly developeda term whose full value I shall hereafter have occasion to discuss-do not really serve to distinguish it from other things; neither does its peculiarity depend upon the proclivity of these pitiful cells to degenerate, nor attach to the free nuclei or central granules. The truth is, that the whole affair is quite out of order in the place where it is found; none of its structures, considered separately, suffice for its identification, but occurring together upon a type which is constantly repeating itself, they are eminently significant.

Lymphous elements proceeding out of connective tissue are no anomaly; but lymphlike cells arising out of connective tissue by endogenous multiplica- tion, and showing no further capacity of developing intercellular substance about themselves, coming to press against each other, so as to impair each other's shape and interfere with each other's nutrition, quickly reproducing more nuclei, which pass no higher, but pulverise again into amorphous matterthis entire group of changes I apprehend to be not only peculiar, but pathognomonic. Developed there by a wrong method, and in a part which ought to present nothing of its kind, tubercle is a new growth, capable of being recognised by its characteristic build.

It does not develope de novo out of a blastema ; it is organised from the first moment that we are able to recognise it, although essentially incapable of high organisation.

When a caseous or cretaceous mass is presented for our examination, we are justified in deciding upon its pathological nature only from our knowledge of its mode of origin. If there be no appearances in or about it which correspond with the structures above described, we have no right to call it tubercle; and we shall act wisely, if, with Professor Virchow, we restrict the application of this term within these limits.

The simple cellular tuberculum is rarely much larger than a pea; but this, which may perhaps be taken as its extremest size, is occasionally reached in the mucous membrane of the intestines, and in the fibrous sheath of the gall-ducts. In the stroma of the liver and kidney, I have often alighted upon tubercles which were so small as to be only microscopically visible.

I shall next consider the form and shape attained by the tuberculous growth in the progress of its further development; for it remains to be shown, what Carswell first propounded, how much this is affected by external influences.

Tubercle in parts like thick false membrane, or firm fibrous tissue, does not attain its natural shape, or degenerate quite in its ordinary way. The eruption of small-pox is a very different affair upon a mucous membrane from what it is upon the skin. Occurring in a firm fibrous tissue, and removed a certain distance from vascular supplies, it partakes in some degree of the nature of its matrix, and is proportionately disinclined to soften and break down.

Virchow designates this the fibrous form. It is the infiltration-form of the older writers, who were not slow to recognise it as tubercle by reason of more typical appearances in its immediate neighbourhood. Its development is on this wise. The connective tissue-cells are impressed with doubly wrong propensities. While certain of them give birth to a degenerate brood of tubercle-elements, certain others pursue a less vicious bent; the nuclei divide again and again, but attain a certain fibrillation, so as to produce an ordinary hyperplastic increase of substance. The two changes may complicate each other in every possible degree; but it is found that the further off blood-vessels heteroplasia* and hyperplasiat are being conducted," the more the hyperplastic aim predominates. In this way, an enormously thickened mass can be produced, whose surface is perfectly smooth.

Rokitansky very conveniently attributed this condition of things to an origin of the substance out of mixed blastemata, ssying that the tuberculous exudation was capable of mixture with simple fibrinous or croupo-fibrinous lymph in all proportions. Closer investigation, however, interprets the affair not merely

- Heteroplasia signifies increase by development of new cell-elements dissimilar to those proper to the part.

+ Hyperplasia signifies increase of gize by multiplication of nor mally preexisting cell-olements. 
more reasonably, but more accurately in accordance with the doctrines of a cellular pathology.

In the formation of false membranes, as in pleurisy, for example, the organisation begins in contact with previously organised parts. A clear fluid may exude from congested capillaries into the cavity of the pleura ; but the cell-proliferation, by means of which new tissue actually is formed, proceeds from one or other serous surface. A section of the thickened pleura demonstrates these cells in several layers of progressive growth, the embryonal forms lying deepest. Now, in several places, these cells remain sufficiently long in situ to flatten, lengthen out, and adhere or fuse together at their edges, so as to form a permanent surface; but every where this is not so. A large portion of the growing cells bud out, as it were, into the fluid by which they are bathed, itself an unfavourable item towards their persistence, and are shed off in this, their embryonal state. Here, then, is development into an exuded fluid, not out of it; and the assumption of these free floating cells having originated de novo in the fluid is gratuitous, incapable of proof, and unlikely, because contrary to our experience of development in other parts.

I recently had occasion to examine an enormously thickened tuberculous mesentery, coming from an adult, who had died of tuberculosis. The appearances were such as, I think, could only be explained upon the hypothesis of intermingled growths.

The surface of the mass was perfectly smooth, neither nodular nor wart-like; so that one might fairly have questioned the existence of tubercle in it at all, if our conception of this had been derived from the idea of knobs or knots, and tubercle-corpuscles, such as Lebert described, were not forthcoming in it. Upon section, irregular whorts or upheavings of some transparent pearl-like substance, set in a much more opaque felt-like material, could be seen by the naked eye. Beneath the microscope, the non-transparent parts were observed to be composed of connective tissue-cells in process of ordinary hyperplasia, clear nuclei multiplying every where, and being every where round and distinct; but in the opaquer parts were situated larger and more irregularly outlined nuclei, which had a granular look, and were mixed in all proportions with amozphous matter. These last were the tubercular heteroplasias. Here were the elements of tubercle-nuclei in process of rapid disintegration into molecular forms. But the manner in which the growths were dovetailed into each other, like the compound papillæ of the skin in the mucous layers of the epidermis, showing groups of distinct elements united together by transitional forms, left no other method except that of co-development and common source of origin to explain their interweavings. One might as reasonably pretend of a linen sheeting in which the regular in-and-out cross thread marked the passage of the shuttle, that it had been cast, like metal gates, in a mould.

The Ordinary Course of the Tubercular Growth.

The elements of tubercle are eminently short lived and prone to degenerate; and the natural course of this degeneration is a fat metamorphosis. It is a moot question, if tubercle can ever be reabsorbed without passing through this retrograde step. Virchow speaks to the possibility of such complete resolution taking place (Würzburg. Verhand., B. vi, \&. xi), and there are some few clinical observations rendering it not improbable.

The fat-metamorphosis of the tubercle-cell differs in many respects from ordinary fat-degeneration. This change in a renal epithelium or catarrhal mucuscell may be taken as the type of the usual process, according to which the fat-granules accumulate in the cell, then run together into one or more fat-drops in its interior, and distend and destroy it; but in the tubercle-growth, from the very commencement of the change, the cells diminish in size, shrivelling from loss of fluid contents; while the fat which dots both cells and nuclei with fine opaque granules presents no tendency to run into oil-globules.

It is this feature of a retrogressive metamorphosis, conducted under conditions of peculiar deficiency in moisture, which affixes a special stamp to the subsequent proceedings.

Thus the simplest issue of the most uncomplicated form of tubercle is a species of dry crumble from within outwards. The denser, more tough, and more fibrous the structure is in which tubercle is developed, the more slowly this retrogressive change is brought about; whereas, the softer and moister the matrix-tissue of the growth, the more rapidly this breaks down and shells out. An intermediate state of its surroundings, in which these are neither especially moist nor dry-of course, the most common condition-favours the transition of tubercle into a cheesy mass, and its persistence in this stage.

Finally, grey and yellow tubercle differ from each other only in the amount of accidental fat-elements they respectively contain, the more yellow tubercle being the one naturally richer in fat. The miliary nodule, seated in the parenchyma of a solid organ, tends to soften in its centre; the grey granular tubercle, seated upon a free surface, softens at a weak point; peripheral softening affects only the conglomerate form, and the change then ensues, not spontaneously from any innate propensity in the mass itself, but is induced entirely by external influences, such as inflammation or excess of moisture in the neighbouring tissues.

The Progress of the Tubercle-Growth under particular External Conditions: Tubercle passing into Ulcer.

When superficially situated upon a mucous membrane, as upon the larynx, tubercle presents us an example of its most rapid degeneration. The growth here takes place subject to conditions of greatest external moisture. The caseous state is then not reached; and the whole softens and shells out, leaving an ulcer which, from the rapidity of its formation and non-cheesy nature, was for a long time not supposed to be of tuberculous origin. Louis entertained the idea that these ulcers were no more than excoriations produced by the acridity of the phthisical sputum (Louis, Recher. Anat. Path. et Thér. sur la Phthisie, Paris, 1843, p. 51). Virchow recommends them, however, as very typical instances of the course of the growth (Virchow, Krank. Geschwïlst, B. ii, s. 645). The ulcer which has thus begun may extend into the submucous tissue, and its walls can then become infiltrated with characteristic cheesy material; but, in the larynx, these sores rarely attain to a size larger than that of an ordinary split pea.

The turther progress of such tubercular ulcers is best studied upon the mucous membrane of the bladder. They spread at their edges and in their floors, the submucous tissue thickening enormously beneath them, and becoming the seat of crop after crop of new growths. At almost any period of their existence, the walls can soften a little further; clear themselves by secretion of real pus; heal up and scar over, as is often seen in the intestines, where the ensuing constriction is not always the most favourable event. But, for the most part, the sores extend one into the other, forming irregularly branched rodent ulcers, with thick overhanging borders. Malignant, exactly, they are not; but there can be no question of their infectious nature. The 
disease spreads by propinquity (juxtaposition); and the scar-tissue of an old tuberculous ulcer is the favourite place for new nodules to form in.

The only two tissues that appear able to resist actual disintegration, among the débris of tubercular ulcers, are bone and elastic tissue. These, although dead and separated, for long retain their characteristic microscopical features unchanged.

$$
\text { [To be continued.] }
$$

\section{ON PARAFFO-STEARINE:}

A SUbstitute For starch, PlAster of PARIs, AND SUCH-LIKE SUBSTANCES, IN BANDAGES AND SPLINTS.

By JAMES STARTIN, Esq., F.R.C.S., Senior Surgeon to the Hospital for Diseases of the Skin, etc.

For a few months past I have been using what appears to me to be an inexpensive, useful, cleanly, elegant, and efficient desideratum, in the treatment of varicose veins and diseased joints, instead of strapping, and also in all maladies or injuries where rest, equable support, and solidity of the parts affected, are required. This consists in immersing "Domett flannel", "Welsh flannel gauze", the woven elastic or other bandage, or felt, either the common carpet felt or that prepared for surgical purposes, in a combination of equal parts of rock paraffine and stearine, as used for candles, which may be coloured to a flesh-tint with alkanet root, and liquified to a little beyond the melting-point $\left(160^{\circ} \mathrm{Fahr}\right.$.), so as to render the composition of a temperature that may be readily manipulated without injury to the hand or part on which it is applied. Rollers or felt, the latter cut into the shape of the splint required, are to be saturated with the above melted composition, and applied whilst warm and flexible to the limb or joint; when, if needed, further strength and solidity may be given by varnishing a portion of the melted composition over the splint or bandage with a painter's brush, and afterwards smoothing the whole with the palm of the hand, until it assumes the surface of ivory, or the well known appearance of a paraffine or stearine candle. A fold of linen, dipped in cold water, is finally to be passed round the bandage or splint, which immediately solidifies the melted paraffo-stearine, when the application is complete; and the wet linen may be continued as an evaporating lotion, if desired. Into this bandage or splint, openings may be readily cut by means of scissors curved on their cutting edge into the segment of a circle, or bent to an obtuse angle; the melted composition being afterwards applied over the cut edges of the opening, so as to form a complete solid case, allowing the escape, through such openings, of discharges, and the application of dressings. It will be perceived that, by dividing the paraffo-stearine bandage, and removing, say half an inch, or separating it into halves, and trimming the edges in the usual manner, splints will be formed having the exact configuration of the part to which they are to be applied, and that these splints can be lined with flannel, wash leather, etc., and strengthened with the melted paraffo-stearine to any extent required.

Mr. Ewen, Jermyn Street, the well known plaster and bandage manufacturer, has undertaken to prepare and furnish these appliances, accompanied by directions for their employment.* Each bandage will be found soaked in paraffo-stearine, with a portion of the prepared composition in its containing canister, for varnishing the bandage or splint, if needed, after it has been tightly and evenly rolled, or applied to the affected part. The felt is supplied in sheets of convenient size, saturated with the composition, from which the splints can be cut, and after they have been moulded to the part requiring them as described.

All that is needed before employing these appliances, as prepared ready for use, is to put the canister containing the bandage and a portion of the paraffo-etearine for varnishing into boiling water until liquified; and the piece of prepared felt may be held before a fire or immersed in water a little below the boiling point, until it acquires the requisite flexibility, when it can be fixed where required by the ordinary procedure, varnished and finished by the aid of the canister of paraffostearine and brush sold with it, and finally solidified by surrounding it with linen dipped in cold water. Or, the whole of the appliances described can be readily extemporised by the aid of a pound or two of paraffine or stearine candles, a jug or jar in a saucepan of boiling water for melting the same, a rolled flannel, Domett, or other bandage, and a shaving-brush; or, should a splint and not a bandage be preferred, a strip of felt carpet, cut into the required shape, and also rolled together, so as to be immersed in the melted candle composition in the jar.

I have found that the best mode of procuring the stearine, or rock paraffin, when a moderate quantity only is required, is to purchase the candles (socalled) from any respectable tradesmon or the candle-companies, asking for the stearine candles used for India, the melting point of which is about $157^{\circ}$ Fahr. (the cost is one shilling a pound); or the rock paraffine, which melt at $135^{\circ}$, and cost the same price, at Messrs. Neighbour and Sons, Regent Street. I have observed that a mixture of the two sorts of candles is"the most suitable; but either one of them can, of course, be used separately. If this be done, however, the paraffine should be employed in winter and the stearine in summer; and I may observe that all the bandages and splints may, by remelting, be used a second or third time, thus rendering them amongst the most economical of applications; and it may also be well to mention that, when the removal of a bandage is required, it may be at once softened and taken off by brushing it over with any of the benzines used for cleaning gloves; that of Farey of Regent Street being the most suitable.t Each variety of benzine mentioned, according to my experience of several years, will be found a most useful surgical accessory, not only to clean the skin and hair from all their natural or acquired oily or sebaceous secretions, but also to remove grease, plasters, etc., from the cutaneous surface without causing local irritation; and, for these purposes, I have much pleasure in introducing it as a therapeutic agent to the profession, which has the property (as I often say to my patients) of cleansing a living skin as effectually as a dead one; and for such purposes, I doubt not, it will come into general requisition, perhaps even as extensively as glycerine, which I introduced twenty-four ago, and which I have lived to find the subject of memoirs and special treatises advocating its employment for the purposes for which I originally recommended it, without even the mention of my name.

* They will also be prepared by Messrs. Savory and Moore of Now Boud Street.

+ Purified Benzine can also be obtained of Messrs. Taylor of Vere Street, Savory and Moore of New Bond Street, Waugh of Regent Street, etc. 